\title{
Analysis of Small Family Business in Gondanglegi Malang District
}

\author{
Affan Afian* \\ Faculty of Economics and Business \\ University PGRI Kanjuruhan Malang \\ Malang, Indonesia \\ *affanafian@unikama.ac.id
}

\begin{abstract}
The purpose of this research is to find, analyse and build theories on family business. The subjects of this research are three family businesses that have been run by two generations. The three research subjects are located in Gondanglegi, Malang Regency. Referring to these objectives, the research was carried out with an inductive approach using qualitative methods and a strategy to construct the theory of research findings was a multicross case study. There are several propositions found in this study as theoretical input on the development of family businesses: (1) Entrepreneurial values in the family business of the Gondanglegi community appear naturally in all generations, with higher educational backgrounds and the latest information insights make Entrepreneurial values increasingly exist; (2) Small family business are not like a professionally managed organizational culture, there is no professional management system, there are no formal business agreements between family members, and the HR recruitment system is also carried out differently from conventional company. The general organizational culture that exists in conventional companies cannot be fully applied to family businesses at the three sites in this study; (3) The dynamics of family business development that occur are highly dependent on the ability of leaders to run and develop a family business. In the first generation its development tends to slow down, while in the second generation its development is very rapid, the scale of business globally increases many times over; (4) Succession in the family business can exist when there is full, sincere, free support from the old and the new generations. Succession in the family business also closes the opportunity for others outside the family members to enter the family business. The process of introducing a business is carried out by parents to their future generations from an early age, this can be seen from the efforts of parents to carefully see and connect the desires of their children with the family business that is being carried out.
\end{abstract}

Keywords—family business, entrepreneurial values, succession

\section{INTRODUCTION}

Indonesia has a GDP equivalent to Turkey and the Netherlands, as well as Indonesia's annual growth rate in the range of $5.8-6.4 \%$. Indonesia is predicted to be the 4th largest economic power in the world in 2050 and with its rapid industrialization, Indonesia is also increasingly attractive for foreign investors to enter. More than $95 \%$ of businesses in Indonesia are family owned, in Southeast Asia, $60 \%$ of public companies (tbk.) Are family companies and inheritance leadership is considered one of the company's priorities [1].

Family companies occupy an important position in the economies of many countries in the world, in the United States it is estimated that 96 percent of all companies are family companies, in Italy the number is less about 93 percent, in Chile it is 75 percent, in Belgium it is 70 percent, in Spain it is. 75 percent while in Australia family companies account for 75 percent of the total business units [2]. In many countries, family business is the dominant company category compared to conventional companies.

Research on family business has increased sharply in the last two decades, this can be seen from the increasing number of studies on the theme of family business. Poza states that more than eighty percent of companies developing around the world are family businesses, so this makes family businesses interesting to research [3]. Currently, there are a lot of family businesses, ranging from small to large ones. Among these family companies, not all of them were able to survive, many family companies were unable to continue their business in the next generation, until in the end the company went bankrupt or moved to become someone else's owner. This kind of thing, of course, is not wanted by the owners of the family company, they started the business with a very long vision and the company should be able to continue to grow from time to time. This dynamic is one of the researchers' interests to research more on how the family business can continue from one generation to the next.

Walsh in his research concluded "While the majority of family business owners would like to see their business transferred to the next generation, it is estimate that $70 \%$ will not survive into the 2nd generation and $90 \%$ will not make it to the 3rd generation" [4]. Free translation, the majority of family business owners want to see their business passed on to the next generation, it is estimated that $70 \%$ will not last until the second generation and $90 \%$ will not make it to the third generation. If calculated in total, then of the $100 \%$ existing family businesses, only $3 \%$ can survive until the third 
generation, meaning that keeping this family business in order to survive in the next generation is extremely difficult. Working professionally is not enough, it has to be done with heart, because there are family members involved, it takes more patience if a conflict occurs, termination of employment cannot be done just like that because it is still tied to your relationship. This is what makes the family business unique as in figure 1 .

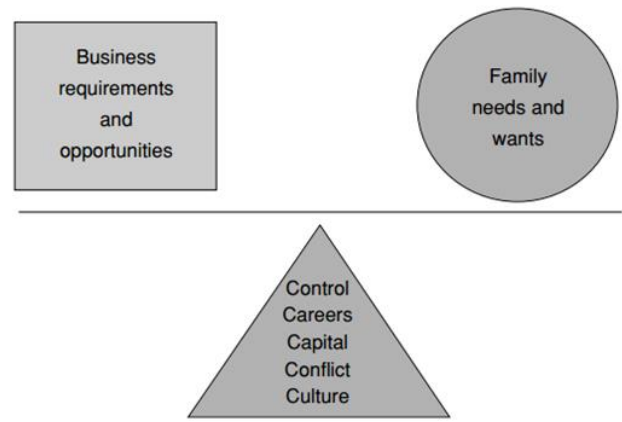

Fig. 1. Family business dilemma [5]

A family business must be able to balance what the family needs and wants with the needs and opportunities in the business. Family business is different from conventional companies, over time, sometimes business requirements and opportunities are not in line with family needs and wants, the result is a gap or conflict, the impact of this gap or conflict can trigger cracks in business and family relationships. Company is any form of business that runs any type of business that is permanent and continuous and which is established, works and is domiciled in the territory of the Republic of Indonesia, for the purpose of obtaining profit and / or profit. There are many things that distinguish family businesses from conventional companies, including leadership, strategic planning, customer and market focus, measurement, analysis and knowledge management, focus on human resources, process management, and business results [6].

One example of differences in the leadership section is as follows, leading a family business and leading other than a family business cannot be equated. A conventional company leader can do professional, authoritarian, and even iron fist things, the leader is not afraid that his employees will feel at home working or not. Employees who make mistakes can be dealt with firmly, through direct warning or warning letters that the company usually does to its employees. This is certainly different from a family business, if the employee makes a mistake and his status is a child or sibling, the treatment of a leader in the family business towards the employee will be different from that of a leader in a non-family business, a harsh and firm warning or a warning letter may not will happen, given that the employee who made the mistake is the child or brother of the leader, the sense of caring and compassion will be higher when compared to someone who is not blood related in general.
Changes will continue to occur, even the map of market changes and business competition will also change. Changes in the business world will bring up five new paradigms in the family business, including employees, labour issues, increasing levels of family professionalism, demands for fair and equal compensation and finally transparency [6].

We have also encountered many issues related to labour, strikes and others recently. The level of family professionalism has begun to increase, the second generation usually has a higher level of education than the first generation, in addition to higher education they are usually more professional. Demands for fair and equal compensation, usually family businesses have begun to open up to this and these demands are linked to competence, performance or contribution. The last part of the new paradigm is that the remuneration system, human resources and organization are more transparent.

Managing a family business is more complicated and complex when compared to managing a conventional company or non-family business, there are several issues that must be faced by family businesses and dealing with family members. A family business must pay attention to these seven issues, including value conflict, succession, management structure, alignment, compensation, competence, and revenue distribution [6]. These issues are not often found in a nonfamily business because they can be done easily, but in a family business they are often found and occur, even many family businesses collapsed and went bankrupt because they could not solve these issues. These developing issues are also the uniqueness of a family business.

The main challenges for Indonesian family businesses in the next two years will be access to the right skills and abilities, the need to innovate to stay ahead, the economic environment and competition. In terms of important personal and business goals, nurturing the best talent (through recruitment and retention) for the business is essential. Innovation and profitability are also key [7].

The success of a family business can achieve two things, first is being able to overcome problems that are happening and second is maintaining good relationships with other family members [8]. Problems that are happening and developing in a family business if not managed properly can make problems in the company not be resolved, even the worse impact of family breakdowns cannot be avoided. Even if the problem is resolved, it still leaves a rift in the family relationship, it cannot be said to be successful.

The development of the family business cannot be separated from the influence of the leadership succession applied by every leader in each generation. Leadership succession is very influential on the continuity of the family company. The potential conflict that occurs in the succession of leadership in the family business is a conflict of values that occurs between the founder who still acts as the driving force of the main business and family members who are then involved in the company. Given that the new generation tends to have a different view, because generally the level of 
education they take is higher than the previous generation. Succession is a crucial issue, especially if the company's control has begun to move towards the second generation, let alone the third generation. Issues in succession include unclear succession plans and conflicts between succession candidates. The key word in succession is when and to whom the company will be inherited. So that conflict between succession candidates does not occur, it is necessary to plan a leadership succession. The succession planning is also intended so that there is no struggle for positions and rights in the family company so that the family also remains peaceful and harmonious [6].

In its development, a family business that has been successful can develop into a large or multinational company that expands its company by spin-off or in other ways, the spinoff manager can be a member of the core family or not but are still in touch with the parent company. Sometimes new firms are the result of cooperation between existing firms and entrepreneurs, these new firms are generally referred to as spinoff firms [9]. Even in a small family business, it is also possible for a spin-off to occur, the research subjects taken in this study are several family businesses that are classified as MSME also do a spin-off.

Based on the research context above, the focus of the research is as follows; 1 . What are the entrepreneurial values in the family business 2 . How are the business ties in the family business; 3 . What are the dynamics of the family business development; 4 . How is the succession of the family business.

\section{METHODS}

The approach used in this research is qualitative. Qualitative research is often called naturalistic because researchers are interested in investigating events as they occur naturally [10]. This qualitative approach was chosen for the following reasons: (1) the existing reality is basically multiple, constructed and holistic; (2) between people who know (knower) and what is known (known) are interactive and inseparable; (3) only time and context are possible in relation to the working hypothesis; (4) all existing entities are in a simultaneous state so that it is almost impossible to distinguish between cause and effect; and (5) research is not essentially free of value [10].

The qualitative approach in this research is more natural, descriptive, and inductive. Natural means that the research background is a natural direct source of data, so researchers must be able to enter directly into the research background of several family businesses in Gondanglegi. The descriptive nature means that the data collected is in the form of words and pictures about the family business, so that to provide support for the descriptions presented in the research report, quotes from the data are disclosed as a result of disclosure of respondents or key informants. The search for data in this study is not to prove or reject the hypothesis because there is no hypothesis, but to make an abstraction when specific facts have been collected and grouped together, which means that the analysis in this study is inductive.

This type of research is case cross analysis, case cross analysis is a part of case analysis. There are two types of case analysis research, namely the single case study research process and the multiple case study research process. The two processes basically refer to the same basic process. The difference is in the number of cases in multiple case study studies that are more than one, so it requires a longer replicative process to integrate the study results from each case [11].

\section{RESULTS AND DISCUSSIONS}

\section{A. Entrepreneurial Value of Small Family Businesses}

In one, the process of creativity instilled by parents in children is almost invisible, but parents fully support if the child has an idea or ideas to develop a family business. Although it is recognized that parents do not instil much creativity in children, children can develop their creativity, confidence and communication.

Children learn to be creative from various things, be it in a shop or in school and college, the fruit of the child's creativity is that he can change the shop from manual stock management to automatic, and successfully run the third supermarket in Dampit, four in Wonokerto and five in Landungsari, and it looks like it will soon open in another area.

On the third site, parents form leadership in children by giving little responsibility for something. One example is that children are asked to shop for groceries with a certain amount of money, children are required to be able to get products at the cheapest price and of good quality. The next example is, when parents have a need to leave the house, children are given the responsibility of running the shop, taking care of employees and store supplies.

At the initial meeting, the researchers dig up information about the educational background of Mr. Naim's sons and daughters, the first child who graduated from bachelor's degree in marketing management, the second son who graduated from bachelor's degree in architecture. When they were asked why they chose that major in the past, they explained that they chose the major at the encouragement of their parents. Parents are less able to instil creativity in children, but parents are able to encourage their children to become creative people like now and have the skills that are needed in their family business, parents have such a vision implicitly.

The findings in this study on three small family business sites in Gondanglegi, the owner cannot run a business with an authoritarian and tough leadership pattern, the leaders of these three small family businesses run their business flexibly, their role as company leaders and parents must work all. Patience is also an important point in this business bond.

The next finding is that parents shape the value of leadership in future generations through simple behaviours, 
including giving small responsibilities for something. One example is telling children to shop for groceries in the city, the nominal amount of money spent is tens of millions, even though they were still teenagers, and they could complete the task well. This is done so that children have a sense of responsibility, having a sense of responsibility is one of the provisions to become leaders.

\section{B. Business Ties in Family Business}

Of the three sites studied, there are several findings that resulted from the research results described in chapter three, including work discipline, management, and human resources.

In family companies in the three sites in this study, the condition of work discipline is very loose, this is done to maintain family harmony. On the three sites in this study simultaneously, if work discipline is strictly applied, conflict will occur. When conflicts occur, work will not be optimal, and this has a huge impact on the running family business.

Work discipline on the three sites is very lax, but violations are very rare, this is one of the uniqueness of the family business. Researchers carried out an extension of research time or additional interviews with several employees, to check that this condition turned out to be true, the employees explained that they really tried not to come to discipline or not be late, because the family business owner had been in the location since the morning, meaning that he arrived early. So, when someone comes late, the owner will find out directly, and they feel reluctant or "embarrassed" about the situation, the same condition occurs when they come home from work, they will feel reluctant if they go home before work hours. The findings in this section are that, although discipline is not strictly applied, minimal violations occur because they feel "uncomfortable" with the owner.

Loose discipline or the owner's patience in managing the business is also the key to success in this family business.

On the first site, HR recruitment cannot be done completely professionally like in conventional companies, recruitment is done through old employee references and the reference provider is fully responsible for the HR performance. The responsibility referred to by the leader is if the employee does not work optimally then the one who is responsible is the employee who gives the reference. When the owner is asked, what kind of example of responsibility is the owner explaining, for example, an employee is caught stealing, then the employee and the referral giver replace him Another example, when an employee often comes late, the first to reprimand him is the reference provider, so that the problem doesn't get to the top, it can be resolved below.

On the second site, the owner recruits prospective employees using a zoning system or candidates for employees who are selected and prioritized are employees who live around the family business location. The owner did this because he wanted to empower the surrounding community, the business I built had to be more or less beneficial for the surrounding community.

Researchers try to dig deeper into this context, what is the impact of the owner choosing employees with locations around the business premises. After re-interviewing employees regarding their activities during lunch breaks, there are findings that, during lunch breaks, most of the employees' activities are: resting, praying, eating, sleeping and bathing. Employees start to take a break at noon when the sound of Dhuhr Adhan and reenter at 1:00 p.m., they have a break between 90 minutes to 70 minutes, depending on the Dhuhr Adhan schedule between 11.30 and 11.50. Employees traveling from work to home are very close, so they have maximum rest time.

Employees at the family business location on site two, can get the maximum income, because they eat lunch at home, even they go to work mostly on foot, they can save twice as much, transportation costs and minimal lunch costs.

\section{Dynamics of Family Business Development Equations}

The dynamics of the development of Mr. Alwi's family business consists of two phases, the first phase is that the family business is only run by Mr. Alwi, and the second phase is the family business run by Mr. Alwi and his two children. The dynamics of the development of Mr. Naim's family business consists of two phases as well. The first phase is a family business run by Mr. Naim alone, and the second phase is a family business run by Mr. Naim and his two children. The dynamics of Mrs. Ida's family business development consists of two phases. The first phase is a family business run by Mrs. Ida and the second phase is a family business run by Mrs. Ida and her two children.

Communication, good relations and active participation between parents and future generations largely determine where the company is going, whether the company will continue to grow or not. Without the active participation of future generations in the family business, parents will find it difficult to continue the family business if their condition is old. In the first phase of the three company development sites tend to be slower, the type of business is not growing much. If connected with educational background, adaptation to technology.

\section{Succession in Family Business}

Family businesses at three different sites in Gondanglegi can develop for decades, the key is communication, good relations and active participation of the next generation in the family business.

\section{CONCLUSION}

The conclusion from the three sites is that parents feel less able to instil creativity in children. One of the sites, their parents said that to be honest they were confused about how to develop a creative spirit in their sons and daughters, they said, "I didn't finish my elementary school, my cell phone might not 
work and call me sms". It can be concluded that educational background and the ability to access information are several reasons why parents have difficulty instilling creativity in children.

Entrepreneurial values in the family business of the Gondanglegi community appear naturally in all generations, with higher educational backgrounds and the latest insight into information that makes entrepreneurial values more existent.

Business ties in the family business are not like a professionally managed organizational culture, there is no professional management system, there are no formal business agreements between family members, and the HR recruitment system is also carried out differently from conventional companies. The general organizational culture that exists in conventional companies cannot be fully applied to family businesses in the three sites in this study.

The dynamics of family business development that occur are very dependent on the ability of leaders to run and develop a family business, in the first generation its development tends to slow down, while in the second generation its development is very rapid, the scale of business globally has increased many times.

Succession in the family business can exist when there is full, sincere, and free support from both old and new generations. Succession in the family business also closes the opportunity for others outside the family members to enter the family business. The process of introducing a business is carried out by parents to their future generations from an early age, this can be seen from the efforts of parents to carefully see and connect the desires of their children with the family business that is being carried out.

\section{REFERENCES}

[1] M. Davies, "Survey Bisnis Keluarga [Online]. Retrieved from: https://www.pwc.com/id/en/publications/assets/Family-BusinessSurvey-2014-Country-Report-Indonesia.pdf, Accessed on: 16 February 2015, 2014.

[2] International Family Enterprise Research Academy, Hoboken, New Jersey: Family Firm Institute, Inc., 2003.

[3] E.J. Poza, Family Business 3E. Ohio: South-Western Cengage Learning Publisher, 2010.

[4] G. Walsh, Family Business Succession Managing the All-Important Family Component. Swiss: KPMG International Cooperative, 2011.

[5] R.S. Carlock and L.W. John, Strategic Planning for the Family Business. New York: PALGRAVE, 2001.

[6] A.B. Susanto, H. Wijanarko, P. Susanto and S. Mertosono, The Jakarta Consulting Group On Family Business. Jakarta: Publishing Division The Jakarta Consulting Group, 2007.

[7] W. Tanudiredja, "Family Business Survey 2018 Indonesia Report [Online]. Retrieved from: https://www.pwc.com/id/en/epc/fbs-2018indonesia.pdf, Accessed on: 18 November 2018, 2018.

[8] C.L. Waisner, Through The Eyes of The Family: A Collective Case Study of Family Business Consulting. Disertasi. Los Angeles: Leadership \& Change Program, Antioch University, 2012.

[9] S. Koster, Whose child? How existing firm foster new firm formation: individuale start ups, spin-outs and spin-offs. Groningen: University of Groningen, 2006.

[10] S. Akbar, Pembelajaran Nilai Kewirausahaan dalam Perspektif Pendidikan Umum: Prinsip-prinsip dan Vektor-vektor Percepatan Proses Internalisasi Nilai Kewirausahaan. Malang: Penerbit Universitas Negeri Malang, 2007.

[11] R.K. Yin, Studi Kasus, Desain dan Metode. Jakarta: Raja Grafindo Persada, 2003. 